\title{
Pengetahuan Mahasiswa Universitas Airlangga Mengenai Dispepsia, Gastritis, dan Gerd beserta Antasida sebagai Pengobatannya
}

\author{
Friesca S. Nurhaidah, Shafira D. Anugrah, Annisa F. Putri, Aisyia, Wiwin D. R. Tukloy, Kambarwati N. Shofa, \\ Salsabila Khairunnisa, Luthfia H. Primadani, Tri Wahyudi, Abby R. Kamaruzzaman, Yunita Nita* \\ Departemen Farmasi Komunitas, Fakultas Farmasi, Universitas Airlangga \\ Gedung Nanizar Zaman Joenoes Kampus C, Jl. Ir. Soekarno, Surabaya 60115, Indonesia \\ *E-mail: yunita-n@ff.unair.ac.id
}

\begin{abstract}
ABSTRAK
Peningkatan kasus penyakit tidak menular terjadi dalam 5 tahun terakhir di Indonesia, salah satunya adalah indigestion yang merupakan sekumpulan gejala saluran pencernaan atas meliputi rasa nyeri atau tidak nyaman di area gastroduodenum. Yang termasuk dalam indigestion diantaranya dispepsia, gastritis, dan GERD dimana seringkali antasida digunakan sebagai terapi pengobatan pada ketiga penyakit tersebut. Penelitian ini bertujuan untuk mengetahui perbedaan pengetahuan mahasiswa fakultas kesehatan dan non-kesehatan Universitas Airlangga mengenai dispepsia, gastritis dan GERD dan penggunaan obat antasida. Penelitian ini dilakukan menggunakan metode survei cross sectional, dengan instrumen kuesioner online. Sejumlah 102 orang, mahasiswa fakultas kesehatan sebanyak 30 orang dan non kesehatan sebanyak 72 orang diambil dengan teknik accidental sampling. Hasil penelitian menunjukkan tingkat pengetahuan semua orang mengenai dispepsia, gastritis dan GERD yang baik sebesar 12 (11,8\%) orang cukup sebesar $40(39,2 \%)$ orang, dan kurang sebesar $50(49 \%)$ orang. Tingkat pengetahuan semua orang pada aspek pengobatan yang baik sebesar $8(7,8 \%)$ orang, cukup $35(34,3 \%)$ orang, dan kurang sebesar $59(57,8 \%)$ orang. Adanya perbedaan bermakna $(p=0,000)$ tingkat pengetahuan antara sampel mahasiswa kesehatan dan sampel mahasiswa non-kesehatan. Upaya promosi kesehatan merupakan hal penting untuk meningkatkan pengetahuan mahasiswa mengenai perbedaan dispepsia, gastritis, GERD beserta antasida sebagai pengobatan.
\end{abstract}

Kata Kunci: Pengetahuan, Dispepsia, Gastritis, GERD, Antasida

\begin{abstract}
The increase in non-communicable disease cases has occurred for the last 5 years in Indonesia. One of them is indigestion, which is a group of symptoms of the upper digestive tract including pain or discomfort in the gastroduodenal area. Indigestion includes dyspepsia, gastritis, and GERD where antacids are often used as treatment. This study aims to determine the difference of knowledge of health and non-health faculty students at Universitas Airlangga regarding dyspepsia, gastritis, and GERD and the use of antacid. This research used cross sectional survey method, with an online questionnaire instrument. A total of 102 students, 30 health students and 72 non-health students were taken using accidental sampling technique. The results showed that the knowledge regarding dyspepsia, gastritis, and GERD was good in $12(11.8 \%)$ students, sufficient in $40(39.2 \%)$ students, and lacking in $50(49 \%)$ students. Meanwhile, the knowledge regarding antacid was good in 8 (7.8\%) students, sufficient in $35(34.3 \%)$ students, and lacking in 59 $(57.8 \%)$ students. There was a significant difference $(p=0.000)$ in the level of knowledge between samples of health and non-health students. Health promotions are important to increase student knowledge about the differences between dyspepsia, gastritis, GERD and antacids as treatment.
\end{abstract}

Keywords: Knowledge, Dyspepsia, Gastritis, GERD, Antacid 


\section{PENDAHULUAN}

Kesehatan Indonesia saat ini sedang dihadapkan pada dua masalah yaitu penanganan penyakit menular dan tidak menular. Selama lima tahun terakhir, Indonesia mengalami peningkatan kasus penyakit tidak menular yang cukup tinggi salah satu penyakit tidak menular ialah indigestion (Kementerian Kesehatan RI Badan Penelitian dan Pengembangan, 2018).

Indigestion merupakan kumpulan gejala saluran pencernaan atas meliputi rasa nyeri atau tidak nyaman di area gastro-duodenum, rasa terbakar, cepat kenyang, mual atau muntah. Beberapa kelompok penyakit yang tergolong dalam indigestion antara lain adalah dispepsia, gastritis dan GERD (Gastroesophageal reflux disease) (Kementerian Kesehatan RI, 2013). Ketiga penyakit tersebut memiliki beberapa gejala yang hampir sama yaitu adanya rasa sakit pada daerah sekitar ulu hati, meskipun penyebabnya berbeda (Fraser et al., 2005).

Definisi dari dispepsia, gastritis dan GERD berbeda. Dispepsia merupakan gejala penyakit pada gastrointestinal bagian atas yang biasanya yang muncul selama 4 minggu atau lebih. Gejala tidak terbatas nyeri atau rasa tidak nyaman pada perut bagian atas namun juga mulas, refluks lambung, kembung, mual dan / atau muntah (Joint Formulary Committee, 2020). Gastritis merupakan suatu penyakit peradangan pada lapisan lambung (Parker and Parker, 2000). Gejala gastritis yaitu sensasi terbakar di belakang tulang dada yang mungkin menjalar ke leher atau tenggorokan saja tanpa ada rasa asam di mulut (Berardi et al., 2009). Sementara itu, GERD merupakan peradangan pada mukosa esofagus yang disebabkan oleh refluks isi lambung ke kerongkongan (Kamienski and Keogh, 2006).

Kesadaran masyarakat Indonesia yang masih sangat rendah mengenai pentingnya menjaga kesehatan lambung serta pengetahuan yang kurang tentang penyakit dispepsia, gastritis dan GERD menjadi penyebab tingginya angka prevalensi ketiga penyakit tersebut di Indonesia (Mulat, 2016; Octaviana, 2018; (Huzaifah, 2017; Darmawan et al., 2019). Untuk kasus penyakit dispepsia pada tahun 2020 diperkirakan angka kejadiannya terjadi peningkatan yang cukup signifikan, dari 10 juta jiwa menjadi 28 juta jiwa setara dengan $11,3 \%$ dari keseluruhan penduduk di Indonesia, sedangkan prevalensi kasus gastritis di Indonesia pada tahun 2014 mencapai 40,8\% (Jung, 2011). Prevelensi penyakit GERD di Indonesia juga mengalami peningkatan akhir- akhir ini. Tarigan (2019) melaporkan prevalensi GERD di Rumah Sakit Dr. Ciptomangunkusumo meningkat 5,7\% pada tahun 1997 menjadi 25,18\% pada tahun 2002 (Tarigan, 2019).

Angka prevalensi yang tinggi dan meningkat ini serta gejala yang diberikan menggambarkan ketiga penyakit tersebut akan sangat mengganggu aktivitas sehari-hari, baik bagi remaja maupun orang dewasa (Octaviana, 2018). Pada kategori usia remaja yaitu 10-
19 tahun cenderung ditemui pada seorang pelajar maupun mahasiswa yang memiliki rutinitas sangat banyak, pola aktivitas yang padat sehingga membuat seseorang stres dan sering mengabaikan atau menunda waktu makan, sehingga dapat menyebabkan mahasiswa terkena penyakit dispepsia, gastritis, dan GERD (Putri et al., 2015; Fithriyana, 2018; Widiyanto, 2014; Widiyanto and Khaironi, 2015; Furnawan et al., 2014).

Dikarenakan mahasiswa beresiko besar menderita penyakit tersebut, seringkali mahasiswa melakukan swamedikasi. Dalam penelitian Handayani (2013) menunjukkan bahwa ada perbedaan antara perilaku responden yang memiliki latar belakang ilmu kesehatan dan non kesehatan, mayoritas responden yang memiliki latar belakang ilmu kesehatan memiliki perilaku lebih baik dalam hal swamedikasi dibandingkan responden yang memiliki latar belakang ilmu non kesehatan.

Produk antasida merupakan salah satu produk obat bebas dan terapinya dapat dilakukan secara swamedikasi (Direktorat Bina Farmasi Komunitas dan Klinik, 2006). Antasida merupakan obat yang biasa digunakan untuk mengatasi dispepsia, gastritis, dan GERD (Parakh et al., 2018). Antasida dapat bekerja dengan cepat, tidak diserap ke dalam tubuh dan durasi kerja lama (Nathan, 2008)

Pentingnya penelitian ini dilakukan karena pada dasarnya gejala awal ketiga penyakit ini serupa, tetapi bila gejala semakin parah akan menunjukan perbedaan gejala lanjut serta membutuhkan penanganan yang berbeda. Sehingga tujuan penelitian ini dilakukan untuk mengetahui pengetahuan mahasiswa Universitas Airlangga mengenai dispepsia, gastritis dan GERD beserta pengobatannya serta mengetahui perbedaan pengetahuan mahasiswa fakultas kesehatan dan non kesehatan Universitas Airlangga terhadap dispepsia, gastritis dan GERD serta penggunaan obat antasida sebagai pengobatannya

\section{METODE PENELITIAN}

Penelitian dilakukan di Universitas Airlangga, Surabaya, Jawa Timur, Indonesia pada bulan Oktober 2020. Penelitian ini merupakan metode cross sectional. Survei dilakukan dengan teknik accidental sampling.

\section{Besar Sampel}

Populasi pada penelitian ini adalah mahasiswa Universitas Airlangga. Sampel pada penelitian ini adalah mahasiswa Universitas Airlangga yang memenuhi kriteria inklusi, yaitu mahasiswa aktif (2016-2020) Universitas Airlangga yang bersedia menjadi orang yang dibedakan menjadi fakultas kesehatan dan fakultas non kesehatan yang pernah menggunakan antasida, kecuali mahasiswa Fakultas Psikologi dan Fakultas Farmasi karena digunakan sebagai responden uji validitas. Populasi mahasiswa 
yang besar dan tidak diketahui secara pasti jumlahnya sehingga dilakukan perhitungan besar sampel minimal dengan menggunakan rumus satu parameter proporsi populasi, yaitu:

Keterangan:

$$
\mathrm{n}=(Z a)^{2} \frac{[P(1-P)]^{2}}{E^{2}}
$$

$\mathrm{n}=$ jumlah sampel minimal yang diperlukan

$\mathrm{Z} \alpha=$ nilai standar dari distribusi sesuai nilai $\alpha=$ $5 \%=1,96$

$\mathrm{P}=$ perkiraan atau estimasi proporsi populasi yang digunakan adalah 50\%,

$\mathrm{E}=$ penyimpangan mutlak yang ditoleransi yaitu $10 \%$.

Sesuai rumus tersebut, jumlah sampel minimal adalah 97 orang. Untuk menentukan jumlah sampel pada masing-masing kelompok, digunakan rumus alokasi proporsional:

$$
\mathrm{ni}=\frac{\mathrm{Ni} \times \mathrm{n}}{\mathrm{N}}
$$

Keterangan :

ni=Besarnya sampel untuk masing-masing kelompok kesehatan atau non kesehatan (kesehatan=27; non kesehatan=70)

$\mathrm{Ni}=$ Total mahasiswa masing-masing kelompok kesehatan dan non kesehatan (kesehatan=6.457; non kesehatan $=17.129$ )

$\mathrm{N}=$ Total mahasiswa Universitas Airlangga selain Fakultas Psikologi dan Farmasi yaitu 23.586 orang $\mathrm{n}=$ Besar sampel yaitu 97 orang

Sesuai rumus tersebut, jumlah sampel minimal untuk mahasiswa kesehatan yaitu sebanyak 27 orang dan mahasiswa non kesehatan sebanyak 70 orang. Dalam pengambilan data didapatkan 102 orang, dengan mahasiswa kesehatan sebanyak 30 orang dan non kesehatan sebanyak 72 orang.

\section{Variabel}

Variabel penelitian berupa pengetahuan mengenai perbedaan dispepsia, gastritis dan GERD beserta antasida sebagai pengobatannya terdiri dari beberapa indikator pada tabel 1 .

\begin{tabular}{|c|c|}
\hline Variabel & Indikator \\
\hline \multirow{5}{*}{$\begin{array}{c}\text { Pengetahuan mengenai } \\
\text { dispepsia, gastritis dan } \\
\text { GERD }\end{array}$} & Definisi \\
\hline & Gejala \\
\hline & Penyebab/pemicu \\
\hline & Risk factor \\
\hline & Terapi non obat \\
\hline \multirow{6}{*}{ survey } & Fungsi antasida \\
\hline & $\begin{array}{l}\text { Bentuk sediaan dan nama } \\
\text { dagang }\end{array}$ \\
\hline & Cara penggunaan antasida \\
\hline & Efek samping \\
\hline & Kontraindikasi dan resiko \\
\hline & Interaksiobat \\
\hline
\end{tabular}

Tabel 1. Variabel Penelitian

\section{Instrumen}

Penelitian ini menggunakan instrumen kuesioner dilakukan dengan online survey. Kuesioner berisikan 15 butir pernyataan yang terdiri dari 7 butir pernyataan tentang perbedaan dispepsia, gastritis dan GERD dan 8 butir pernyataan tentang pengetahuan mengenai antasida dengan jawaban benar, salah dan tidak tahu.

\section{Validasi}

Dilakukan tahap pendahuluan untuk menilai validitas instrumen yang digunakan. Content validity dilakukan dengan membuat item-item pada kuesioner berdasarkan pustaka yang relevan. Kemudian diulas oleh satu orang yang ahli di bidangnya. Face validity dilakukan kepada 20 mahasiswa farmasi, dosen pembimbing dan 20 mahasiswa Universitas Airlangga yang sesuai kriteria inklusi. Setelahnya dilakukan perbaikan berdasarkan saran yang diperoleh, antara lain, menggunakan bahasa yang lebih mudah dipahami, untuk memudahkan pemahaman golongan obat maka dicantumkan contoh obat, dan jumlah pernyataan terlalu banyak. Perbaikan yang dilakukan yaitu pengurangan jumlah pernyataan, dan memperjelas pernyataan yang sulit dipahami

\section{Analisis data}

Pengetahuan dapat diinterpretasikan dengan skala yang bersifat kualitatif, yaitu pengetahuan baik jika memiliki persentase $76-100 \%$, pengetahuan cukup jika memiliki persentase $56-75 \%$, dan pengetahuan kurang jika memiliki persentase $<56 \%$ (Arikunto, 2013). Untuk melihat perbedaan pengetahuan antara sampel mahasiswa fakultas kesehatan dan non kesehatan menggunakan uji statistik Mann-Whitney.

\section{HASIL DAN PEMBAHASAN}

\section{Data demografi}

Penelitian ini menggunakan sampel sejumlah 102 orang. Hasil penelitian dapat dilihat pada tabel 2 yang merupakan data sosiodemografi. Proporsi orang perempuan lebih besar dibandingkan dengan laki-laki yaitu sejumlah $86(84,4 \%)$ orang. Pada penelitian yang dilakukan oleh Atzeni et al. (2015), perempuan tiga kali lebih berisiko terkena gangguan lambung dibandingkan dengan laki-laki.

Berdasarkan rentang usia orang, berada pada rentang usia produktif dengan mayoritas orang berusia 21 tahun sejumlah $48(47,1 \%)$ orang. Kategori usia produktif cenderung memiliki aktivitas yang padat, baik dari kegiatan akademis dan non akademis yang dapat membuat seseorang merasa stres dan mengabaikan atau menunda makan, sehingga dapat berisiko menyebabkan mahasiswa terkena penyakit dispepsia, gastritis dan GERD ((Fithriyana, 2018; 
Widiyanto, 2014; Widiyanto and Khaironi, 2015; Furnawan and Puspitorini, 2014).

Tabel 2. Data demografi Orang

\begin{tabular}{|c|c|c|}
\hline $\begin{array}{l}\text { Demografi } \\
\text { Orang } \\
\end{array}$ & Kategori & $\mathrm{n}(\%)$ \\
\hline \multirow[t]{2}{*}{ Jenis Kelamin } & Laki-Laki & $16(15,7)$ \\
\hline & Perempuan & $86(84,3)$ \\
\hline \multirow[t]{7}{*}{ Usia } & 18 & $3(2,9)$ \\
\hline & 19 & $10(9,8)$ \\
\hline & 20 & $26(25,5)$ \\
\hline & 21 & $48(47,1)$ \\
\hline & 22 & $13(12,7)$ \\
\hline & 23 & $0(0)$ \\
\hline & 24 & $2(2,0)$ \\
\hline \multirow[t]{11}{*}{ Fakultas } & FK & $9(8,8)$ \\
\hline & FKG & $0(0)$ \\
\hline & $\mathrm{FH}$ & $5(4,9)$ \\
\hline & FEB & $14(13,7)$ \\
\hline & FKH & $4(3,9)$ \\
\hline & FISIP & $20(19,6)$ \\
\hline & FST & $16(15,7)$ \\
\hline & FKM & $15(14,7)$ \\
\hline & FIB & $9(8,8)$ \\
\hline & FKP & $2(2,0)$ \\
\hline & FPK & $8(7,8)$ \\
\hline
\end{tabular}

Tabel 3. Pengetahuan tentang Dispepsia, Gastritis dan GERD

\begin{tabular}{|c|c|c|c|}
\hline Indikator & $\begin{array}{c}\mathbf{n}(\%) \\
\text { Jawaban } \\
\text { benar } \\
\text { Responden } \\
\text { kesehatan }\end{array}$ & $\begin{array}{c}\mathbf{n}(\%) \\
\text { Jawaban } \\
\text { benar } \\
\text { Responden } \\
\text { non- } \\
\text { kesehatan } \\
\end{array}$ & $\begin{array}{c}\text { n(\%) } \\
\text { Jawaban } \\
\text { benar Total } \\
\text { Responden }\end{array}$ \\
\hline \multicolumn{4}{|l|}{ Definisi Dispepsia } \\
\hline $\begin{array}{l}\text { Dispepsia adalah kumpulan gejala yang terdiri dari nyeri dan tidak nyaman di ulu } \\
\text { hati. }\end{array}$ & $28(27,45)$ & $28(27,45)$ & $56(54,9)$ \\
\hline \multicolumn{4}{|l|}{ Definisi Gastritis } \\
\hline Luka lecet pada dinding lambung merupakan pengertian dari penyakit gastritis. & $26(25,5)$ & $37(36,3)$ & $63(61,8)$ \\
\hline \multicolumn{4}{|l|}{ Definisi GERD } \\
\hline $\begin{array}{l}\text { Pada GERD, asam lambung naik-turun dari perut menuju kerongkongan } \\
\text { sehingga menyebabkan nyeri pada kerongkongan. }\end{array}$ & $23(22,5)$ & $38(37,3)$ & $61(59,8)$ \\
\hline \multicolumn{4}{|l|}{ Gejala Dispepsia, Gastritis dan GERD } \\
\hline $\begin{array}{l}\text { Gejala khas dispepsia, gastritis, dan GERD yaitu adanya rasa panas pada daerah } \\
\text { lambung. Namun pada GERD juga disertai dengan rasa asam pada daerah mulut. }\end{array}$ & $1(0,98)$ & $2(1,96)$ & $3(2,94)$ \\
\hline \multicolumn{4}{|l|}{ Penyebab Gastritis } \\
\hline $\begin{array}{l}\text { Salah satu penyebab gastritis adalah penggunaan OAINS (Obat Anti Inflamasi } \\
\text { Non Steroid) seperti Asam Mefenamat dalam jangka waktu yang cukup panjang. }\end{array}$ & $23(22,5)$ & $17(16,7)$ & $40(39,2)$ \\
\hline $\begin{array}{l}\text { Mengonsumsi kopi dan alkohol secara terus menerus serta pola makan yang } \\
\text { tidak teratur dan tidak sehat dapat menyebabkan dispepsia, gastritis, dan GERD. }\end{array}$ & $30(29,4)$ & $64(62,7)$ & $94(92,2)$ \\
\hline \multicolumn{4}{|l|}{ Faktor Resiko } \\
\hline $\begin{array}{l}\text { Salah satu faktor yang dapat meningkatkan risiko terkena penyakit GERD ialah } \\
\text { obesitas. }\end{array}$ & $14(13,7)$ & $20(19,6)$ & $34(33,3)$ \\
\hline
\end{tabular}

\section{Data pengetahuan}

Profil pengetahuan orang terkait definisi, gejala, faktor risiko penyakit dispepsia, gastritis dan GERD ditunjukkan pada tabel 3 sebanyak $56(54,9 \%)$ orang mengetahui definisi dari dispepsia yaitu sindrom atau kumpulan gejala yang terdiri dari nyeri atau rasa tidak nyaman di gastrointestinal bagian atas dengan gejala yang biasanya muncul selama 4 minggu atau lebih (Joint Formulary Committee, 2020). Sementara itu, pada indikator definisi gastritis, sebanyak $63(61,8 \%)$ orang mengetahui bahwa gastritis adalah suatu penyakit luka atau lecet pada mukosa lambung (Parker and Parker, 2000). Sebanyak 61 (59,8\%) orang mengetahui definisi GERD yaitu suatu keadaan patologis perdangan yang terjadi akibat refluks isi lambung ke dalam mukosa esofagus (Kamienski and Keogh, 2006). Hanya 3 (2,94\%) orang mengetahui bahwa gejala khas dari ketiga penyakit tersebut berbeda yaitu dispepsia terdapat tidak nyaman pada perut bagian atas namun juga mulas, kembung, mual atau muntah (Joint Formulary Committee, 2020), gastritis adanya rasa terbakar di belakang tulang dada yang mungkin menjalar ke leher atau tenggorokan tanpa ada rasa asam di mulut (Berardi et al., 2009) sedangkan GERD terdapat sensasi seperti rasa terbakar hingga kerongkongan (Dipiro, Schwinghammer and Wells, 2015). Ketiga penyakit tersebut memiliki gejala yang hampir sama namun berbeda penyebabnya. Kesalahan dalam mengenali gejala dari ketiga penyakit tersebut menyebabkan keparahan dari penyakit serta kesalahan dalam pemilihan terapi (Fraser, Delaney and Moayyedi, 2005). 
Faktor penyebab munculnya penyakit juga menjadi parameter pengetahuan orang mengenai ketiga penyakit tersebut. Sebanyak $40 \quad(39,2 \%)$ orang menjawab benar bahwa penggunaan OAINS (Obat Anti Inflamasi Non Steroid) dalam jangka waktu panjang merupakan salah satu penyebab gastritis. Menurut Dipiro (2015) gastritis disebabkan oleh beberapa faktor utama, seperti infeksi Helicobacter pylori dan penggunaan OAINS jangka panjang. Selain itu faktor-faktor lain yang dapat menyebabkan dispepsia, gastritis dan GERD adalah konsumsi kopi, alkohol dan pola makan yang tidak teratur, dimana hal ini dijawab dengan benar oleh hampir seluruh orang yaitu $94(92,2 \%)$ orang. Salah satu faktor risiko GERD adalah obesitas, dimana sebanyak $34(33,3 \%)$ orang menjawab dengan benar. Hal ini dapat berbahaya bagi pasien obesitas karena dapat memperparah keadaan pasien melalui peningkatan tekanan intra abdomen, penurunan tekanan Lower Esopagheal Sphincter (LES), serta peningkatan kadar TNF- $\alpha$ dan IL-6 (Emerenziani et al., 2013).

Mengenai fungsi antasida sebagai terapi pengobatan, sebanyak $68(66,7 \%)$ orang menjawab benar bahwa antasida untuk mengatasi gejala ringan gangguan nyeri pada ulu hati dengan cara mengurangi asam lambung. Antasida difungsikan sebagai pengobatan utama gangguan pencernaan (Nathan, 2008). Sementara itu, tentang interaksi antasida dengan obat lain, hanya sebanyak $28(27,5 \%)$ orang mengetahui bahwa antasida dapat diminum dua jam setelah pemberian obat lain seperti ketoconazole. Kurangnya pengetahuan tersebut dapat menyebabkan obat menjadi kurang efektif, meningkatkan toksisitas obat, menyebabkan efek samping bahkan dapat membahayakan nyawa (Andayani, 2020). Selain itu, mengenai pernyataan onset of action sediaan, hampir separuh dari total orang yaitu $41(40,2 \%)$ orang menjawab benar bahwa antasida tablet tidak lebih cepat dibandingkan dengan larutan karena sediaan bentuk terlarut akan memberikan efek yang lebih cepat dan efektif (Trianggani et al., 2018)

Mengenai cara penggunaan obat antasida, sebanyak $71(69,6 \%)$ orang menjawab benar bahwa penggunaan antasida tidak boleh digunakan bersama dengan makanan. Hal ini karena makanan mengurangi kontak antasida dengan lambung (Nathan, 2010) sebanyak $83(81,3 \%)$ orang menjawab benar bahwa penggunaan obat antasida cair harus dikocok terlebih dahulu karena bahan aktif tidak dapat bercampur yang berpengaruh terhadap ketidaktepatan dosis (Athijah, 2011). Selain itu, sebanyak $57(55,9 \%)$ orang menjawab benar bahwa antasida hanya diminum ketika merasakan gejala, karena antasida paling baik diberikan saat muncul gejala dan dihentikan saat gejala sudah hilang (Depkes RI, 2008).

Efek samping juga merupakan hal yang penting dalam pengobatan. Terkait hal ini sebanyak $34(33,3 \%)$ orang menjawab benar bahwa salah satu efek samping adalah diare. Selain itu, dari sejumlah 32 (31,4\%) orang mengetahui bahwa antasida menyebabkan anemia dan hypercalcaemia jika digunakan dalam waktu yang lama. Penggunaan antasida dalam jangka waktu lama dapat menimbulkan defisiensi vitamin B12 yang dapat mengakibatkan anemia pernisiosa (Andrès et al., 2007).

Tabel 4. Pengetahuan mengenai Antasida sebagai Pengobatan Dispepsia, Gastritis dan GERD

\begin{tabular}{|c|c|c|c|}
\hline Indikator & $\begin{array}{c}\mathbf{n}(\%) \\
\text { Jawaban benar } \\
\text { Responden } \\
\text { kesehatan }\end{array}$ & $\begin{array}{c}\mathbf{n}(\%) \\
\text { Jawaban benar } \\
\text { Responden non- } \\
\text { kesehatan }\end{array}$ & $\begin{array}{c}\mathbf{n}(\%) \\
\text { Jawaban benar } \\
\text { Total Responden }\end{array}$ \\
\hline \multicolumn{4}{|l|}{ Fungsi Antasida } \\
\hline $\begin{array}{l}\text { Antasida merupakan obat yang dapat mengatasi gejala ringan } \\
\text { pada gangguan nyeri pada ulu hati }\end{array}$ & $26(25,5)$ & $42(41,2)$ & $68(66,7)$ \\
\hline \multicolumn{4}{|l|}{ Interaksi Antasida dengan Obat Lain } \\
\hline $\begin{array}{l}\text { Antasida dapat diminum dua jam setelah pemberian obat lain } \\
\text { seperti obat jamur (Ketoconazole) }\end{array}$ & $11(10,8)$ & $17(16,7)$ & $28(27,5)$ \\
\hline \multicolumn{4}{|l|}{ Onset of Action } \\
\hline $\begin{array}{l}\text { Sediaan antasida tablet bekerja lebih cepat dan efektif } \\
\text { daripada sediaan cair. }\end{array}$ & $16(15,7)$ & $25(24,5)$ & $41(40,2)$ \\
\hline \multicolumn{4}{|l|}{ Cara Penggunaan Antasida } \\
\hline Penggunaan antasida bersamaan dengan makanan. & $28(27,4)$ & $43(42,2)$ & $71(69,6)$ \\
\hline $\begin{array}{l}\text { Sebelum menggunakan antasida cair harus dikocok terlebih } \\
\text { dahulu }\end{array}$ & $28(27,4)$ & $55(53,9)$ & $83(81,3)$ \\
\hline $\begin{array}{l}\text { Antasida diminum sampai habis, walaupun gejala sudah } \\
\text { hilang. }\end{array}$ & $21(20,6)$ & $36(35,3)$ & $57(55,9)$ \\
\hline \multicolumn{4}{|l|}{ Efek yang Ditimbulkan Antasida } \\
\hline Salah satu efek samping penggunaan antasida yaitu diare & $16(15,7)$ & $18(17,6)$ & $34(33,3)$ \\
\hline $\begin{array}{l}\text { Antasida akan menimbulkan anemia dan hypercalcaemia } \\
\text { (kelebihan kalsium dalam darah) jika digunakan dalam } \\
\text { waktu yang lama. }\end{array}$ & $15(14,7)$ & $17(16,7)$ & $32(31,4)$ \\
\hline
\end{tabular}


Berdasarkan tabel 5 pada pengetahuan mengenai perbedaan dispepsia, gastritis dan GERD beserta antasida sebagai pengobatannya, maka diketahui bahwa kategori kurang memiliki jumlah dan persentase paling besar diantara kategori lainnya. Faktor yang mempengaruhi pengetahuan seseorang diantaranya: tingkat pendidikan, paparan media sosial, hubungan sosial atau pekerjaan, pengalaman dan usia (Fauzian et al., 2016).

Sehingga perlu adanya edukasi untuk meningkatkan pengetahuan mengenai penyakit dispepsia, gastritis dan GERD beserta antasida sebagai pengobatannya, dengan cara melakukan promosi kesehatan dengan media audio visual yang dapat dilakukan di pelayanan kefarmasian maupun di sosial media. Penyuluhan dengan menggunakan audio visual membutuhkan indra mata dan penglihatan. Semakin banyak indra yang digunakan untuk menerima sesuatu maka pengetahuan yang diperoleh lebih banyak dan lebih jelas dibandingkan dengan metode lain (Putri, 2017).

Tabel 5. Kategori Tingkat Pengetahuan Kelompok Sampel

Total nilai n $(\%)$

\section{Pernyataan Perbedaan Penyakit}

\begin{tabular}{lc}
\hline $0-3$ & $50(49)$ \\
\hline $4-5$ & $40(39,2)$ \\
\hline $6-7$ & $12(11,8)$ \\
\hline Pernyataan Pengobatan Penyakit \\
\hline $0-4$ & $59(57,8)$ \\
\hline $5-6$ & $35(34,3)$ \\
\hline $7-8$ & $8(7,8)$ \\
\hline \hline
\end{tabular}

Pada uji statistik Mann Whitney didapatkan adanya perbedaan bermakna tingkat pengetahuan antar kelompok sampel mahasiswa fakultas kesehatan dan non kesehatan mengenai perbedaan dispepsia, gastritis dan GERD beserta antasida sebagai pengobatannya (nilai $\mathrm{p}: 0.000<0.005$ ).

Tabel 6. Hasil Uji Mann Whitney

\begin{tabular}{|c|c|c|c|}
\hline Kelompok & $\mathrm{n}$ & Mean & Sig. \\
\hline Kesehatan & 30 & 75.97 & 0.000 \\
\hline $\begin{array}{l}\text { Non } \\
\text { kesehatan }\end{array}$ & 72 & 41.31 & \\
\hline
\end{tabular}

Tingkat pengetahuan mahasiswa fakultas kesehatan lebih tinggi karena dipengaruhi oleh beberapa faktor, antara lain sumber informasi, fasilitas yang dimiliki dan pendidikan formal yang diperoleh (Debora et al., 2018; Handayani et al., 2013). Latar pendidikan formal mahasiswa ini sangat berpengaruh terhadap kepedulian mahasiswa akan kesehatannya sendiri maupun kemampuan mereka untuk menentukan pilihan swamedikasi. Swamedikasi tersebut juga dalam budaya kedokteran maupun mahasiswa dari bidang kesehatan sebagai cara yang diterima untuk meningkatkan kemampuan mereka di bidang Kesehatan (Montgomery et al., 2011).

Adapun keterbatasan dalam penelitian ini diantaranya proporsi distribusi orang perfakultas belum tercapai, sehingga kecenderungan persebaran orang tidak merata. Selain itu, adanya fakultas dalam kriteria inklusi tidak menyumbangkan orang. Fakultas dalam kriteria inklusi yang tidak memberi orang dalam penelitian ini yaitu Fakultas Kedokteran Gigi.

\section{KESIMPULAN}

Berdasarkan penelitian yang dilakukan, pengetahuan sampel mahasiswa Universitas Airlangga mengenai dispepsia, gastritis dan GERD beserta antasida sebagai pengobatannya tergolong kurang dengan persentase terbesar. Ada perbedaan bermakna antara pengetahuan sampel mahasiswa kesehatan dan non kesehatan mengenai perbedaan dispepsia, gastritis dan GERD beserta antasida sebagai pengobatannya. Dengan demikian, perlu dilakukan edukasi dengan melakukan promosi kesehatan untuk meningkatkan pengetahuan tersebut.

\section{UCAPAN TERIMA KASIH}

Penulis mengucapkan terima kasih kepada Bapak apt. Catur Dian Setiawan S. Farm., M.Kes. selaku dosen yang telah membimbing dan memberi masukan dalam pengolahan data, para responden, serta seluruh pihak yang terlibat dalam penelitian ini.

\section{DAFTAR PUSTAKA}

Andayani T. M. (2020) Drug Related Problem: Identifikasi Faktor Resiko dan Pencegahannya. Yogyakarta : Gadjah Mada Press

Andrès, E. et al. (2007) 'B12 Deficiency: A Look Beyond Pernicious Anemia', Journal Of Family Practice, 56(7), pp. 537-542.

Arikunto. (2013) Dasar-Dasar Evaluasi Pendidikan. Jakarta : Bumi Aksara.

Atzeni, F. Et Al. (2015) 'Helicobacter Pylori Infection And Gastric Autoimmunity: Coincidence Or A Cause And Effect Relationship 2nd Edition'. Journal Infection And Autoimmunity.

Berardi, R. R. Et Al. (2009). Handbook Of Nonprescription Drugs: An Interactive Approach To Self-Care. Washington DC : American Pharmacists Association.

Darmawan, M. D. Et Al. (2019) 'Analisis pengetahuan gerd pada siswa kelas 12 Man Insan Cendekia Serpong tahun ajaran 2018 / 2019', Jurnal Fakultas Kedokteran Univeristas Sebelas Maret Surakarta.

Debora, V., Oktarlina, R. Z., Perdani, R. R. W. (2018) 
'Perbedaan tingkat pengetahuan, persepsi, dan pengalaman terhadap penggunaan obat generik pada mahasiswa kedokteran dan non kedokteran di Universitas Lampung', Jurnal Majority, 7(2). pp. 24-33.

Departemen Kesehatan RI. (2008) Materi pelatihan peningkatan pengetahuan dan keterampilan memilih obat bagi tenaga kesehatan. Jakarta: Departemen Kesehatan RI.

Dipiro, J. T. (2015) Pharmacotherapy handbook 9th edition. New York: Mc Graw Hill.

Direktorat Bina Farmasi Komunitas dan Klinik. (2006) Pedoman Penggunaan Obat Bebas dan Bebas Terbatas Departemen Kesehatan Republik Indonesia. Jakarta: Departemen Kesehatan Republik Indonesia.

Emerenziani, S., Rescio, M. P., Guarino, M. P. L., Cicala, M. (2013) 'Gastro-esophageal reflux disease and obesity, where is the link?. World', Journal Of Gastroenterology, 19(39). pp. 65366539. doi: $10.3748 /$ wjg.v19.i39.6536

Fauzian, R., Rahmi, F. and Nugroho, T. (2016) 'Hubungan tingkat pengetahuan dengan perilaku memeriksakan diri ke pelayanan kesehatan : penelitian pada pasien glaukoma di Rumah Sakit Dr. Kariadi', Jurnal Kedokteran Diponegoro, 5(4), pp. 1634-1641. doi: https://doi.org/10.14710/dmj.v5i4.15911

Fithriyana, R. (2018) 'Faktor-faktor yang berhubungan dengan kejadian dispepsia pada pasien di willayah kerja Puskesmas Bangkinang Kota', Prepotif Jurnal Kesehatan Masyarakat, 2(2). pp. 43-54. Doi: https://doi.org/10.31004/prepotif.v2i2.79

Fraser, A., Delaney, B. and Moayyedi, P. (2005) 'Symptom-based outcome measures for dyspepsia and gerd trials: a systematic review', American Journal Of Gastroenterology, 100(2), pp. 442-452. Doi: 10.1111/j.15720241.2005.40122.x

Furnawan, H., And Puspitorini, S. (2014) 'Rancang bangun aplikasi penentuan tingkat risiko penyakit gastroesofageal reflux disease (gerd) berdasarkan pola makan, gaya hidup, dan status gizi dengan pohon keputusan konsep entropy', Jurnal Akademika, 13(1), pp. 19073984.

Handayani, D. T., Sudarso And Kusuma, A. M. (2013) 'Swamedikasi pada mahasiswa kesehatan dan non kesehatan', Jurnal Manajemen dan Pelayanan Farmasi, 3(3), pp. 197-202.

Huzaifah, Z. (2017) 'Hubungan pengetahuan tentang penyebab gastritis dengan perilaku pencegahan gastritis', Healthy-Mu Journal, 1(1). pp. 28-31.

Joint Formulary Committee. (2020) British National Formulary 80. London: Bmj Group and Pharmaceutical Press.

Jung, H. K. (2011) 'Epidemiology of gastroesophageal reflux disease in asia: a systematic review', Journal Of Neurogastroenterology And Motility, 17 (1). pp. 14-27.

Kamienski, M. and Keogh, J. (2006) Pharmacology Demystified. New York : Mc Graw Hill.

Kementerian Kesehatan RI. (2013) Riset Kesehatan Dasar 2013. Badan Penelitian dan Pengembangan Kesehatan Kementerian Kesehatan RI.

Kementerian Kesehatan RI (2018) Hasil Utama Riset Kesehatan Dasar. Badan Penelitian dan Pengembangan Kesehatan Kementerian Kesehatan RI.

Montgomery, A. J., Bradley, C., Rochfort, A., \& Panagopolou, E. (2011) 'A review of selfmedication in physicians and medical students', Occupational Medicine, 61(7), pp. 490-497

Mulat, T. M. (2016) 'Tingkat pengetahuan dan sikap masyarakat terhadap penyakit gastritis di wilayah kerja Puskesmas Barombong Kota Makassar', Jurnal Ilmiah Kesehatan Sandi Husada, 4(1), pp. 30-37.

Nathan. (2010). Non-Presciption Medicines 4th Edition. London: Pharmaceutical Press.

Nathan, et al. (2008). Symptoms In The Pharmacy. London: Pharmaceutical Press.

Octaviana, E. S. L. (2018) 'Faktor-faktor yang berhubungan dengan upaya keluarga dalam pencegahan penyakit dispepsia di wilayah kerja puskesmas mangkatip kabupaten barito selatan', Jurnal Langsat, 5(1), pp. 11-14.

Parakh, R. K. And Patil, N. S. (2018) 'Anaesthetic antacids: a review of its pharmacological properties and therapeutic efficacy', International Journal of Research In Medical Sciences, 6(2), pp. 383-393. doi: http://dx.doi.org/10.18203/23206012.ijrms20180005

Parker, J. N. And Parker, P. M. (2000). The Official Patient's Sourcebook On Gastritis. San Diego : Icon Group International Inc.

Putri, A. T., Rezal, F., Akifah.(2017) 'Efektifitas media audio visual dan leaflet terhadap peningkatan pengetahuan, sikap dan tindakan tentang pencegahan penyakit gastritis pada santriwati di Pondok Pesantren Hidayatullah Putri dan Ummusshabri Kota Kendari Tahun 2017', Journal of Chemical Information And Modeling, 53(9), pp. 1689-1699. doi: 10.37887/jimkesmas.v2i6.2869

Putri, R. N., Ernalia, Y. and Bebasari, E. (2015) 'Gambaran Sindroma Dispepsia Fungsional Pada mahasiswa Fakultas Kedokteran Universitas Riau angkatan 2014', Jurnal Online Mahasiswa Fakultas Kedokteran Universitas Riau, 2(2), pp. 3-18.

Tarigan, R., and Pratomo, B., (2019) 'Analisis faktor risiko gastroesofageal refluks Di RSUD Saiful 
Anwar Malang', Jurnal Penyakit Dalam Indonesia, 6(2), pp. 78-81. doi: http://dx.doi.org/10.7454/jpdi.v6i2.306

Trianggani, D. F., and Sulistiyaningsih. (2018) 'Artikel tinjauan: dispersi padat', Jurnal Farmaka Fakultas Farmasi Univeristas Padjajaran, 16(1), pp. 93-102.

Widiyanto, J. et al. (2014) 'Hubungan antara tingkat stres dengan kejadian gastritis', Jurnal Photon : Sain dan Kesehatan, 5(1), pp. 29-32.

Widiyanto, J. and Khaironi, M. (2015) 'Hubungan antara tingkat stres dengan kejadian gastritis (study di Puskesmas Harapan Ra ya Pekanbaru)', Jurnal Photon, 5(2). pp. 111-118. doi: $\quad$ https://doi.org/10.37859/jp.v5i1.191 